ISCKMC 2020

International Scientific Congress «KNOWLEDGE, MAN AND CIVILIZATION»

\title{
TEACHING RUSSIAN TO ARAB STUDENTS USING THE RESOURCES OF THEIR NATIVE LANGUAGE
}

\author{
Bella K. Zakaeva (a)*, Zema E. Gelieva (b), Olga N. Boldyreva (c), Maria V. Suntsova (d), \\ Evgeniy Y. Vidanov (e), Irina L. Mul (f), Yulia Y. Litvinenko (g), Natalia V. Vagenlyatner (h) \\ *Corresponding author
}

(a) North Caucasian Institute of Mining and Metallurgy (State Technological University), 44, Nikolaeva str., Vladikavkaz, Russia, zbllbella@yahoo.com

(b) North Caucasian Institute of Mining and Metallurgy (State Technological University), 44, Nikolaeva str., Vladikavkaz, Russia, zema-gelieva@yandex.ru

(c) Kalmyk State University named after B.B. Gorodovikov, 11, Pushkina str., Elista, Russia,

Olya.boldyreva2013@yandex.ru

(d) Kaluga State University named after K.E. Tsiolkovski, 26, Stepana Razina str., Kaluga, Russia, maria.suncova@gmail.com

(e) Omsk State Pedagogical University, 14, Naberezhnaya Tukhachevskogo, Omsk, Russia, vidanov@omgpu.r u

(f) Omsk State Pedagogical University, 14, Naberezhnaya Tukhachevskogo, Omsk, Russia, mul.alex@mail.ru

(g) Omsk State Pedagogical University, 14, Naberezhnaya Tukhachevskogo, Omsk, Russia, julitv@mail.ru

(h) Omsk State Pedagogical University, 14, Naberezhnaya Tukhachevskogo, Omsk, Russia, natalia_wg@mail.ru

\begin{abstract}
The article is devoted to the problem of teaching foreign languages and pays attention to the challenges Arabs often face while learning Russian. The process of learning the second and subsequent languages is undoubtedly influenced by the student's mother tongue. The authors identify two types of linguistic interference: conscious and spontaneous. The researchers believe it is necessary to make maximum use of the conscious interference potential because it can become the basis of methodological techniques for teaching L2. They are sure the L1 and L2 differences and similarities that should be used and their ignoring can complicate the process of mastering the target language. The article also examines the features of the phonetic and graphic similarities and differences of the Arabic and Russian language. The authors note that Arab students should be taught the art of beautiful handwriting in Russian, since Arabic writing and Cyrillic differ significantly. Great attention is paid to the comparative characteristics of Arabic and Russian sounds, the importance of correct pronunciation and the need for development of the phonemic consciousness of the learners. The objective of the research is to find proper ways to diminish the difficulties when learning Russian as a foreign language by Arab learners.
\end{abstract}




\section{Introduction}

There is a great variety of languages all over the Earth. The language (L1) we hear and use from the first days of our birth is our mother tongue. Any other language that people obtain is the second (L2), the third (L3), etc., language. "Second language acquisition or SLA is the process of learning other languages in addition to the native language" (Hoque, 2017, para. 8). Competencies in a second language are acquired in two ways: in the process of subconscious perception, similar to how a person learns to speak in childhood and in the process of learning a language (Krashen, 1982).

Hardly anyone doubts that the learner's native language (L1) influences on the second language (L2) acquisition and the proper linguistic competencies formation (Littlewood \& Yu, 2009). Ignoring differences and similarities of the native and target languages can complicate the learning process.

\section{Problem Statement}

The goal of our research work is to help teachers and learners to cope with some Russian language aspects learning challenges they face. Arab students have great difficulties with writing in Russian, because Arabic and Russian scripts and sounds differ greatly, so we try to make use of their mother tongue pronunciation skills. In our research work, we try to highlight the challenges Arab students face in learning Russian and offer the ways to cope with the difficulties by using their mother tongue aspects.

\section{Research Questions}

The authors try to answer several questions:

- What are the greatest difficulties for Arab students in learning Russian from the point of view of the scientists, teachers and learners?

- Does L1 have any impact on L2?

- What are the opinions of Russian and international linguists on the L1 impact on L2?

- Do Russian and Arabic have any similarities in characters writing and phonetics?

- Would it be methodologically justified to use L1 as an assistant in L2 learning?

\section{Purpose of the Study}

The purpose of the study is to find methodically justified and suitable ways and methods for effective teaching Arabic learners the Russian language on the basis of their mother tongue.

\section{Research Methods}

The authors used content observation and analysis of theses, monographs, scientific and educational publications, research works in the field of Russian language teaching, Russian and Arabic textbooks and manuals for teaching phonetics and Cyrillic, etc. The work is based on the Arab students' survey to identify the greatest challenges in the Russian language study process. 


\section{Findings}

The aim of our research work is to discover the challenges Arab students face while learning Russian and find the ways to ease the target language acquisition.

To realize the research goals and objectives, we studied contemporary RFL teaching methods; interviewed Arabs studying Russian to identify their challenges; and, on the basis of the obtained data, we propose to use targeted linguistic interference as effective tools for L2 successful study, as conscious interference can be the basis of methodological techniques in teaching L2 (Abdrakhman, 2018).

Russian and international scientists, linguists, methodologists and practicing teachers search for effective methodological foundations for teaching Russian as a foreign language.

Shutova and Orekhova (2018) represent the ways of learning Russian sounds by comparing them with those of the native language. Statsenko and Samokhina (2020) touch upon the sounds pronunciation mastering problem of a specific category of learners. Antibas (2016) shares her experience of correcting Arab students' mistakes while studying the Russian language. Loginova (2017) discusses the problems of teaching Russian pronunciation to non-Russian students.

Lots of foreign scientists and practitioners are also engaged in finding the best ways of teaching Russian. Canadian scientist Marren (2011) touches upon the stress in Russian words, reduced vowels, consonants' stunning and intonation. Jones and Ward (2010) provide a detailed description of Russian sounds, intonation, and stress.

We compared the corollaries made by scientists with the results of our surveys and our long-term observations, and come to the conclusion that for the majority of Arabs the Cyrillic alphabet is an undoubted challenge, since Cyrillic and Arabic scripts fundamentally differ. In fact, the alphabet is not the most complex part of the Russian language, especially for those who are familiar with the Latin alphabet and whose native alphabets are:

- based on the Cyrillic or its elements,

- derived from the Greek or Latin alphabets (Omniglot, 2020).

When introducing the Russian alphabet, the letters can be divided into 4 groups:

1) Аа, Кк, Мм, Оо, Тт.that are similar in writing and reading to the Latin letters;

2) Вв, Еe. Ё̈̈, Нн, Pp, Cc, Уу, Xx, look like Latin letters, but their names are different;

3) Б б, Г г, Д д, Ж ж, 3 з, Ф ф, Ц ц, Ч ч, Ш ш, Щ щ, ы, Э э, Ю ю, Я я, that have no graphical analogues in Latin, but have letters with the same names but different images.

4) $\mathrm{b}, \mathrm{b}$

This way of representing Russian letters does not always work when teaching Arabs, because of the unusual direction of writing from left to right, printed and hand-written letters. Capital and small letters in the Russian language are often the reason for the incorrect writing because Arabic letters are all of the same height. Arabic students persistently start even proper names with small letters. While students can somehow cope with the printed letters writing, handwritten letters are a real challenge for them. Disputes often arise among methodologists on the calligraphy teaching advisability to foreigners, but we believe that the problem should be approached in a differentiated manner. We share Hamraeva's (2015) opinion that teaching Arabs one should pay attention to calligraphy. 
Teaching Russian letters writing, the Arabic script cannot be helpful to us in any way, but there are plenty of similar sounds and the phonetic interference can be a good tool and helper. Though, he role of the mother tongue in the second language learning has been the subject of much discussions and doubts, we are sure in learning speaking, L1 can be very valuable (Yadav,2014).

In order to speak, hear and reproduce sounds correctly one should have phonemic hearing. The main component of any speech, i.e. a person's ability to hear and distinguish phonemes or sounds in a word, to determine the sounds in a word, their number and sequence (Efimenkova, 2006).

Difficulties in speaking the second language are usually caused by L1 interlingual interference, i.e. transferring the native language rules to the target one (Shcherba, 1957). The interlingual interference can be phonetic, lexical, grammatical, etc., and we often use its advantages in our work, for example, in studying sounds, intonation, and so on. Though some educators insist on a complete exclusion of the mother tongue from the second language teaching process, most linguists are not so categorical and allow its use for educational purposes in special cases (Zakaeva \& Bratchik, 2018).

When teaching the sounds of the Russian language, we can adapt phonetic interference of the Arabic language to our methodological needs. Introducing Russian vowel letters and sounds one should mind that there are only three letters in the Arabic language, so 10 of them in Russian at first confused them. So, it is undoubtedly necessary to develop phonemic hearing in students to distinguish the sounds of an unfamiliar language (Bernal \& Ardila, 2016). We also recommend that international students should be introduced to Russian phonetic transcription, which is based on the Cyrillic alphabet with the addition of some letters from other alphabets (Knyazev \& Pozharitskaya, 2003). Russian language learners should be introduced to the transcription symbols of Russian sounds, for example, presented by Hobzová (2011).

Phonetic errors can be rooted in the student's native language, that's why Arabs are not able to identify some Russian vowel sounds, for example, [o] and [y], because Arabic vowel letters can express several sounds depending on the position in the word. Thus, the letter $g$ transmits two sounds: $[o]$ and $[u]$, and the letter $\mathrm{s}$ transmits the sounds [e] and [i].

Arabic learners often ignore writing vowels in Russian words, because in Arabic words they are replaced by so-called "alephs". The sounds [i, u, a] are indicated by alephs under or above the consonant letter, with [a] being a horizontal dash above the letter, [u] being a comma above the consonant. We think they read incorrectly the stress in Russian words because they confuse the stress mark with the aleph.

How can deliberate phonetic interference and the mother tongue of the Arabs help teach correct Russian pronunciation? We recommend to find suitable examples of similar sounds in their native language, but the students should definitely be paid attention to the pronunciation nuances and articulation differences of both languages.

To explain the pronunciation of the Russian sound [a], we can take Arabic words تكبر (takburu you get older) and أيضا [aidan] (also), أبو ظبي [abu dhabi] (Abu Dhabi). The Russian sound [э] is pronounced as the first sound in the word افعلها [efalha] (do!). For the Russian sound [я], the word [Yamaha] (Yamaha) is an example, and for [ю] - يُرْ (yur), يُزْ (yut). There's no equivalent sound to Russian [ы] in Arabic, as in many other languages, indeed. In the Arabic alphabet hard and soft consonants are presented separately, while the same Russian consonant letters and sounds can be hard or soft, voiced or voiceless: [б-б',п-п,,в-в',ф-ф',с-с',з-з', д-д,',т--',г-г',к-к',м-м',н-н',Л-л',р-р',х-х']. Reading of 
Russian consonant letters depends on adjacent letters: after "а,э,ы,o,y", the preceding consonant will be hard, and after “я, е, и, ё ,ю, ь”, respectively, soft. The vowels themselves are neither hard, nor soft; they only affect the preceding consonant letter. In Arabic alphabet you can find consonant letters that are close to the Russian ones in their reading, but all Arabic consonants are relatively hard, though pronounced slightly softer than their Russian counterparts. In Arabic, voiced consonants are not stunned at the end or in the middle of a word, as it happens in Russian. At the same time, it can be noted that hard consonants in Russian have a [э (æ)]-shaped shade (Arabyaz, 2009). The Russian sounds [б], [д], [3], [c] you can

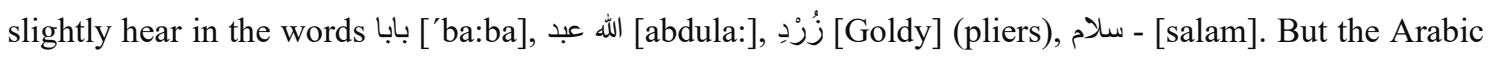
letter د (dal) has an [e]-shaped shade, so Arab students often read [дэвер'] instead of [двер'], [дэрәва:] instead of [дрәва:], etc. This is an example of the negative phonetic interference. When explaining the pronunciation of the Russian sound [ш], take as an example the name of the Arabic letter ش (fi: n). But keep in mind the Arabic sound differs in some softening, while the Russian [w] is always hard. Arab students often say “ш'апка" instead of “шапка", “ш'ишка" instead of “шишка”, etc.

You can hardly find analogues to the sounds [в, г, ж, п, ц, ч, щ] in Arabic, but the sounds relatively close to the Russian [й], [ш], [к,] [м], [н], [р], [т], [ф], [х] are heard in the Arabic words

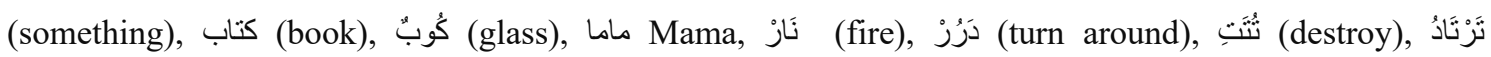
(frequency), خَنَّ (also), خَادِّ (remove) and (servant).

No less a challenge than the aforementioned difficulties is the Russian "floating" stress because any syllable can be under the stress, depending on the form and type of the word. Arabic students often stress the second or third syllable from the end of the word, as it should be in their native language. Besides, there are pairs of Russian words that are spelled in the same way, but having different stress variants. These words have absolutely different meanings, so students should be warned that an incorrectly placed stress can drastically change the meaning of a word. The following words can be given as an example: за́мок - замо́к, стре́лки - стрелки́, пари́ть - па́рить, etc. Furthermore, there are the words with the same meaning, but with different stressed syllables. They usually belong to professional jargons: бápжа - баржа́, и́скра - искра́, добы́ча -до́быча, ко́мпас - компа́c.

\section{Conclusion}

The above features of the Russian language confirm the importance of the following linguodidactic principle: any phonetic phenomenon subject to practical assimilation must be considered from two perspectives: from the point of the system to which L2 belongs (here we mean Russian), and the native language phonetic system (in this case, Arabic). Thus, oral communication skills developing is not possible by simple imitation, as far as it requires conscious mastering of a new, atypical articulation for the inophones, ways of combining sounds, rhythmic-intonation of a word and statement through comparison with similar phenomena of the mother tongue (Lyubimova, 1982).

Summing up, we would like to note that in order to achieve our ultimate goal - the formation of sustainable communicative competencies in Russian, it is undoubtedly necessary to take into account the impact of the students' native language and use it as an additional methodological tool.

When mastering the 12 phonetics, the L1 conscious interference can be very effective, but special attention should be paid to practicing sounds that have no analogues in the student's native language. 
It is important to teach the fundamentals of the target language phonetic system, practice and master the correct pronunciation, intonation and accent. To develop phonemic hearing, learners should read aloud, listen to audio files and people around, watch movies, communicate, etc.

Various kinds of interactive tasks, use of modern technologies and games in teaching can keep students interested in learning a language (Zakaeva et al., 2016). The use of games at the lessons, where active participation encourages students to communicate spontaneously, has a positive effect on communication skills formation (Fedotova \& Kasatkina, 2016).

\section{Acknowledgments}

We use this opportunity to express our gratitude to Fatima Olegovna Abaeva, senior researcher at SOIGSI VSC RAS (Vladikavkaz), for her invaluable help.

\section{References}

Abdrakhman, A. K. (2018). Interlanguage interference and the impact of the globalization process on the Russian language. Aktual'nye problemy filologii. In Materialy III Mezhdunarodnoi nauchnoi konferentsii. Molodoi uchenyi. https://moluch.ru/conf/phil/archive/301/14225/

Antibas, I. A. (2016). Influence of Russian and Arabic languages phonetic differences on teaching Arabic students to read in Russian. Sovremennye kontseptsii nauchnykh issledovanii. Sbornik nauchnykh rabot XIV Mezhdunarodnoi scientific konferentsii. Eurasian association, 2(14), 65-66. https://esaconference.ru/wp-content/uploads/files/pdf/Antibas-Irina-Aleksandrovna.pdf

Arabyaz (2009). Izuchenie arabskogo yazyka. https://arabyaz.livejournal.com/1143.html

Bernal, B., \& Ardila, A. (2016). From hearing sounds to recognizing phonemes: Primary auditory cortex is a truly perceptual language area. AIMS Neuroscience, 3(4), 454-473. https://doi.org/ 10.3934/Neuroscience.2016.4.454

Efimenkova, L. (2006). Korrektsiya oshibok, obuslovlennykh nesformirovannost'yu fonematicheskogo vospriyatiya [Correction of errors caused by unformed phonemic perception]. Knigolyub.

Fedotova, N. L., \& Kasatkina, A. Yu. (2016). Foneticheskie igry pri obuchenii inostrantsev russkomu proiznosheniyu. Obrazovatel'nye tekhnologii $i$ obshchestvo, 19(2), 467-481. https://cyberleninka.ru/article/n/foneticheskie-igry-pri-obuchenii-inostrantsev-russkomuproiznosheniyu

Hamraeva, E. A. (2015). Russkii yazyk dlya detei bilingvov: teoriya i praktika. Uchebnoe posobie [Russian language for bilingual children: theory and practice. Tutorial]. Bilingva.

Hobzová, I. (2011). Praktičeskije upražnenija po fonetike russkogo jazyka [Practical exercises in phonetics of Russian language]. Neuveden.

Hoque, M. (2017). An Introduction to the Second Language Acquisition. EDRC, 1. https://www.researchgate.net/publication/335690866_An_Introduction_to_the_Second_Language Acquisition

Jones, D., \& Ward, D. (2010). The phonetics of Russian. Cambridge University Press.

Knyazev, S. V., \& Pozharitskaya, S. K. (2003). Sovremennyi russii literaturnyi yazyk. Fonetika, grafika, orfografiya. Gaudeamus.

Krashen, S .D. (1982). Principles and practice of second language acquisition. TESOL Quarterly, 17(2). https://doi.org/10.2307/3586656 and https://www.jstor.org/stable/3586656

Littlewood, W., \& Yu, B. (2009). First language and target language in the foreign language classroom. Lang. Teaching, 42(04), 64-77. https://doi.org/10.1017/S0261444809990310

Loginova, I. M. (2017). Modern interpretation of Russian phonetics in teaching pronunciation. Russ. Lang. Abroad, 3(262), 39-45. 
Lyubimova, N. A., (1982). Obuchenie russkomu proiznosheniyu: Artikulyatsiya. Postanovka i korrektsiya zvukov [Teaching Russian pronunciation: Articulation. Setting and correcting sounds]. Russkii yazyk.

Marren, A. (2011). Phonetic perception and pronunciation difficulties of Russian language (From a Canadian Perspective). The Arbutus Rev., 2, 75-93. https://doi.org/10.18357/tar2120119064 and

Omniglot (2020). Russian. The online encyclopedia of writing systems and languages. https://www.omniglot.com

Shcherba, L. V. (1957). Izbrannye trudy po russkomu yazyku [Selected works on the Russian language]. Uchpedgiz.

Shutova, M. N., \& Orekhova, I. A. (2018). Phonetics in teaching Russian as a foreign language. Russ. Lang. Stud., 16(3), 261-278. https://doi.org/10.22363/2618-8163-2018-16-3-261-278

Statsenko, A. N., \& Samokhina, O. V. (2020). Teaching phonetics in Russian as Foreign language classes, following the specifies of the national language. Meridian, 6(40), 162-164. http://meridian-journal.ru/site/article?id=3230

Yadav, M. (2014). The role of mother tongue in second language learning. Int. J. of Res., 1, 572-582. https://www.researchgate.net/publication/330089393_The_Role_of_Mother_ Tongue_in_Second_Language_Learning

Zakaeva, B. K., \& Bratchik, A. B. (2018). Ispol'zovanie rodnogo yazyka uchashchegosya pri obuchenii inostrannomu. V Abaevskie chteniya. In Mezhdunarodnaya nauchnaya konferentsiya, posfyashchennaya 90-letnemu yubileyu fakul'teta osetinskoi filologii SOGU (pp. 149-157). Vladikavkaz: IPTs SOGU. http://www.skgmi-gtu.ru/Portals/0/_Articles3/003650.pdf?ver=201812-14-114427-883

Zakaeva, B. K., Bratchik, A. B., \& Kusov, I. R. (2016). Interactive teaching methods. In Nauka obshchestvu. Trudy V Regional'noi mezhdistsiplinarnoi konferentsii molodykh uchenykh (pp. 328334). VNTs RAN. http://www.skgmi-gtu.ru/Portals/0/_Articles3/004264.pdf?ver=2020-03-12$112823-270$ 